\title{
Lise Bernhardt*
}

\section{Tekstuelle bistrukturer - definition og funktion}

\begin{abstract}
A text can be divided into a main line and "someting else", which is not part of the main line. The main line, which may also be called the main structure of the text, has been defined on various occasions by the use of such terms as "chronological development", "foreground", etc. Furthermore, it has been described as the skeleton of the text. Those parts which are not main structure, and which may be called side structures, have until now only been defined negatively as not being main structure.

This article describes the German researcher Christiane von Stutterheim's definition of main- and side structures. After this it suggests an alternative definition, which provides more insight about side structures, beside the fact that they are not main structure. To reach a more complete description of side structures, this article analyses the functions that side structures have in texts.
\end{abstract}

\section{Formålet med tekstuelle hoved- og bistrukturer}

Formålet med en inddeling af tekster i tekstuelle hoved- og bistrukturer er at undersøge teksters opbygning, særligt med henblik på de enkelte ytringers betydningsbidrag i forhold til hinanden og i forhold til teksternes overordnede budskab. Således er det en måde at undersøge, hvordan tekster er inddelt $\mathrm{i}$ en hovedhandling/et skelet (hovedstruktur) og i andre dele, som falder uden for hovedhandlingen (bistrukturer). På denne måde bliver det muligt at komme nærmere en forståelse af, hvordan budskaber kommunikeres, hvordan mening formuleres, og hvordan en tekstverden i det hele taget opbygges.

\footnotetext{
* Lise Bernhardt

Institut for tysk og nederlandsk

Københavns Universitet

Njalsgade 80

DK-2300 København $S$
} 


\section{Stutterheims definition af tekstuelle hoved- og bistrukturer}

Den hidtil mest udførlige definition af tekstuelle hoved- og bistrukturer stammer fra den tyske lingvist Christiane von Stutterheims quaestioteori. Stutterheims formål med quaestioteorien er at undersøge, hvilke faktorer der styrer en afsenders tekstproduktion $i$ en given situation $i$ hans forsøg på at skabe en kohærent tekst.

Ifølge Stutterheim har afsenderen i tekstproduktionsprocessen nogle retningslinjer for, hvordan teksten som et hele skal være opbygget. Sådanne retningslinjer får afsenderen fra tekstens overordnede quaestio. Et quaestio er et spørgsmål, som en tekst besvarer, og en tekst er kun kohærent, hvis den besvarer et quaestio ${ }^{1}$. Quaestioteoriens grundlæggende udgangspunkt er således, at en tekst skal opfattes som svaret på et sådan spørgsmål:

$$
\begin{aligned}
& \text { „[...] der Text [dient] in seiner Gesamtheit dazu, eine - explizite oder } \\
& \text { implizite - Frage zu beantworten - die Quaestio des Textes. Die } \\
& \text { einzelnen Äußerungen liefern dazu in wohlabgestimmter Weise jeweils } \\
& \text { einen bestimmten Beitrag.“ (Klein/Stutterheim 1987: 163) }
\end{aligned}
$$

Når en afsender producerer en tekst, sker dette altså på baggrund af et bestemt quaestio. Dette quaestio kan enten være eksplicit (afsenderen får stillet spørgsmålet af - normalt - modtageren) eller implicit (tænkt, afsenderen producerer teksten på eget initiativ og forestiller sig et underliggende spørgsmål).

\subsection{Stutterheims hovedstruktur}

Det overordnede quaestio opstiller nogle globale retningslinjer ${ }^{2}$ for afsenderens opbygning af den pågældende tekst og for sammenknytningen af de enkelte ytringer med hinanden. Hvordan den samlede information,

\footnotetext{
1 Begrebet quaestio stammer fra latin og betyder "an inquiry, investigation, a questioning, question, subject of inquiry" (Lewis/Short 1996: 1502). Hos Stutterheim er et quaestio normalt altid et spørgsmål.

2 Med betegnelsen globale retningslinjer menes overordnede egenskaber, der påvirker teksten som et hele modsat lokale retningslinjer, der kun har indflydelse på enkelte ytringer. Der findes ud over quaestios globale retningslinjer også andre globale faktorer (f.eks. afsenderens pragmatiske viden og hans vurdering af modtagerens viden), som dog ikke beskrives nærmere i denne sammenhæng. Retningslinjerne fra quaestio danner dog ifølge Stutterheim det øverste niveau i et hierarki af påvirkningsfaktorer.
} 
der skal udtrykkes, fordeler sig på tekstens enkelte ytringer, er således ikke tilfældig, men er derimod et resultat af, at den samlede tekst tjener til at besvare et bestemt quaestio.

På baggrund af de globale retningslinjer inddeler quaestio tekstens ytringer i to niveauer, nemlig i hoved- og bistrukturer, alt efter om ytringerne er en del af svaret på quaestioet, sådan som quaestioet instruerer til:
,[...] mit der Quaestio [ist] eine strukturelle Vorgabe verbunden, die den Antworttext in zwei Ebenen gliedert: diejenige, zu der Äußerungen gehören, die als Antwort auf den Quaestio anzusehen sind, und diejenige, die alle übrigen Äußerungen umfaßt. Wir sprechen im folgenden von der Hauptstruktur im Hinblick auf diejenigen Äußerungen, die vorga- benkonform sind, und einer heterogenen Gruppe von Nebenstrukturen im Hinblick auf Äußerungen, die Verstöße gegen Vorgaben aufweisen." (Stutterheim 1997: 28)

De ytringer, der er med til at besvare quaestio, tilhører tekstens hovedstruktur. Disse ytringer danner ifølge Stutterheim tekstens rygrad, idet de giver teksten en slags rød tråd, en main line, som afsenderen følger gennem hele sin tekstopbygning, og som sørger for den overordnede tekstkohærens.

For at en ytring kan siges at være med til at besvare tekstens quaestio og dermed være en hovedstrukturytring, skal den overholde visse retningslinjer, som quaestio opstiller. Den vigtigste er, at ytringen skal overholde quaestios krav til udfyldningen af de fem referensområder tid, sted, person/objekt, prædikat (hændelse, handling, tilstand, egenskab) og modalitet og til referentiel bevægelse, som er den måde, hvorpå informationen i teksten inden for de fem referensområder udfolder og udvikler sig fra ytring til ytring (Stutterheim 1997: 56ff).

\subsubsection{Stutterheims bistrukturer}

Quaestiones skal ikke forstås som, at en afsender er tvunget til at følge deres retningslinjer uafbrudt for at skabe en kohærent tekst. Ind imellem hovedstrukturens ytringer kan der normalt skubbes andre ytringer, som har en anden opgave end at være en direkte del af svaret på tekstens overordnede quaestio. Disse ytringer udgør tekstens bistrukturer, der hos Stutterheim udelukkende er defineret negativt ved, at de er ytringer, der ikke er en direkte del af svaret på quaestio og altså ikke overholder quaestios retningslinjer for tekstopbygningen: 
„Nebenstrukturen sind negativ definiert. Sie antworten nicht auf die Quaestio des Textes, obwohl sie natürlich indirekt doch zu der gesamten Antwort beitragen." (Klein/Stutterheim 1987: 181)

Bistrukturerne falder altså uden for teksten hovedstruktur. De danner deres egne enheder, enten i form af en enkelt ytring eller i form af flere sammenhængende ytringer. Bistrukturer kan således være relativt komplekse og i visse tilfælde ligefrem dominere eller endda "kvæle" hovedstrukturen og dermed hele teksten. Hvilke ytringer der er en del af svaret på quaestio og dermed hovedstrukturytringer, og hvilke der er bistrukturytringer, afhænger naturligvis af det enkelte quaestios udformning, altså hvad det specifikt spørger til.

\section{En ny definition af tekstuelle bistrukturer}

Quaestioteorien har visse ulemper. For det første mener Stutterheim, at der til hver teksttype findes specifikke quaestiotyper og, som resultat heraf, specifikke hovedstrukturmønstre. Det er dog langt fra alle tekster, som er homogene på den måde, at der kun er én teksttype repræsenteret i dem. Mange tekster er heterogene, idet forskellige teksttyper er repræsenteret inden for den samme tekst ${ }^{3}$. Ved denne form for typologisk skift inden for den samme tekst opstår der problemer for Stutterheims quaestioteori, idet quaestios krav til hovedstrukturytringerne således må ændre sig, hver gang der er tale om et skift i teksttype. Stutterheim bliver på den måde nødt til at tale om et nyt quaestio, hver gang der opstår et typologisk skift, og således falder forestillingen om, at en tekst indeholder ét overordnet quaestio, til jorden.

For det andet indeholder Stutterheims definitioner en statisk opfattelse af tekster. Der er på forhånd formuleret et quaestio, og hele teksten konstrueres på baggrund af dette. Stutterheims definitioner opstiller altså nogle formalistiske udregningsregler, som på baggrund af quaestio leverer så faste rammer, at der ikke er megen plads til kommunikationspartnernes individualitet. Det er nærmest umuligt for forskellige kommunikationspartnere at komme frem til forskellige resultater med henblik på, hvad der er hovedstrukturen, og hvad der er bistrukturerne i teksten. Sådanne udregningsregler virker dog kunstige og er ikke passende til hverken

3 Man kan dog normalt udpege en teksttype, som dominerer over de andre, og som gør det muligt at klassificere hele teksten som værende én bestemt teksttype. 
tekstproduktions- eller til tekstreceptionsteorier, hvor kommunikationspartnernes individualitet nødvendigvis må spille en afgørende rolle.

Det er derfor nødvendigt at opstille en hoved-/bistrukturdefinition, der tager mere højde for dynamikken hos kommunikationspartnerne og i kommunikationssituationen. Det vil sige, at det er nødvendigt med en hoved-/bistrukturdefinition med et større spillerum for kommunikationspartnernes individuelle opfattelser og forståelse af en given tekst. Der er nemlig ikke garanti for, at flere kommunikationspartnere vil komme frem til samme tekstforståelse af en given tekst og dermed af et givet quaestio. Det er derudover vigtigt, at der også tages hensyn til, at kommunikationspartnerne nogle gange reviderer deres opfattelse af det overordnede quaestio i løbet af tekstproduktionen/-receptionen.

I det hele taget kan det diskuteres, om tekster virkelig altid skal forstås som afsenderens svar på et bagvedliggende spørgsmål, eller om der ikke nærmere bare er tale om et overordnet emne, der søges specificeret. Bliver afsenderen eksplicit stillet et spørgsmål, er det klart, at formålet med hans dernæst producerede tekst normalt vil være at besvare dette spørgsmål. Bliver der derimod ikke stillet et eksplicit spørgsmål, er det mindst lige så sandsynligt, at afsenderen kun forestiller sig et tema, der skal specificeres. Men hvis begrebet quaestio forkastes, falder Stutterheims definition af hoved- og bistrukturer fra hinanden, idet hele definitionen bygger på, om en given ytring er en del af svaret på quaestio eller ej.

I skabelsen af en ny definition af bistrukturer kan i stedet anvendes Gilles Fauconniers teori om mentale rum. Denne kan, hvis den kombineres med Stutterheims oprindelige tanker om at indfange en teksts hovedhandling og dens andre dele, skabe en bistrukturdefinition, der tager højde for ovennævnte kritikpunkter samtidig med, at den kan fortælle os mere om, hvad bistrukturer egentlig er (ud over, at de ikke er en del af tekstens hovedstruktur), idet det bliver muligt at indfange hovedog bistrukturer ud fra, hvilke epistemiske og evidentielle værdier ytringernes sagsforhold har. Dette går godt i spand med Stutterheims egne undersøgelser af den referentielle bevægelse inden for referensområdet modalitet.

Mentale rum udgør modtagerens kognitive organisation af en teksts sagsforhold alt efter deres værdi i forhold til det, der fremstår som sandt 
134

i tekstverdenen, altså det ideationelle udgangspunk $\mathrm{t}^{4}$. De mentale rum kan inddeles efter sagsforholdenes epistemiske og evidentielle værdier. Med epistemisk værdi menes her sagsforholds sandhedsværdi i forhold til det, der fremstår som sandt i tekstverdenen. Sagsforhold, der ikke har samme epistemiske værdi, kan ikke tilhøre samme mentale rum ${ }^{5}$. Med evidentiel værdi menes, at et sagsforholds værdi bestemmes ud fra, hvem der har ytret det. På denne måde spiller udsagnets oprindelige ophavsmand også en rolle i tilskrivningen af værdier til sagsforhold.

Inddeler man mentale rum efter deres epistemiske eller evidentielle værdi, findes der følgende typer mentale rum:

1. Realitetsrum, R (reality space (Fauconnier 1994: 17)). Realitetsrummet er oftest basisrum og dermed målestok for tilskrivningen af epistemiske og evidentielle værdier til alle tekstens sagsforhold. I realitetsrummet har sagsforholdene sandhedsværdien sand i forhold til det ideationelle udgangspunkt i tekstverdenen:

${ }^{R}$ Israel zieht seine Truppen aus dem Libanon zurück-ohne Friedens-
vertrag mit Syrien. ${ }^{R}$ Das stärkt die radikalen Palästinenser. ${ }^{R}$ Der israe-
lische Rückzug aus dem Libanon hat begonnen, sechs Wochen früher
als geplant und unter dem Siegesgeschrei der Hizbullah. ${ }^{R}$ Ein solches
Szenario wollte Ehud Barak unter allen Umständen vermeiden." (Zeit
25.05.00: 9)

2. Generisk rum, G (generics (Fauconnier 1994: 166)). Mens specifikke sagsforhold normalt er bundet til én tid og én lokalitet, gælder generiske sagsforhold for mange tider og lokaliteter. Dermed kan den epistemiske værdi siges at være "mere sand" end den sandhedsværdi, der opereres med i realitetsrum:

${ }^{G}$ Wer wie Deutschland europa- und bündnisfähig sein will, muss auch einsatzfähig sein." (Zeit, 25.05.00: 1)

3. Hypotetisk rum, H (hypothetical space (Fauconnier 1994: 31)), hvor sagsforholdene er hypotetiske, altså (endnu) ikke eksisterende. Disse hypotetiske sagsforhold består af en betingelse, der (endnu) ikke er opfyldt, samt en følge heraf. Betingelsen skal opfyldes, før følgen og

4 Begrebet ideationelt stammer fra Halliday 1996.

5 Dog kan sagsforholds epistemiske værdi gradueres, f.eks. ved hjælp af modale adverbialer, uden at der derved skiftes til et nyt mentalt rum. 
dermed hele det hypotetiske sagsforhold kan realiseres i R. Mens sagsforholdene altid har sandhedsværdien sand inden for $\mathrm{H}$, er de altså (endnu) ikke kompatible med R:

„Henn er nicht nach dann 39 Jahren die Ära sozialdemokratischer Ministerpräsidenten in Nordrhein-Westfalen beschließen will, muss Clement in der kommenden Legislaturperiode sein politisches Meisterstück abliefern." (FAZ 26.05.00: 3)

4. Irrealt rum, IR (counterfactuals (Fauconnier 1994: 109ff)), hvor sagsforholdene udelukkende er tankeeksperimenter. Disse tænkte sagsforhold kan ikke og vil aldrig kunne realiseres i R og er dermed helt non-eksistente og falske i forhold til R, mens de dog altid er sande inden for IR:

"IR Das Parasitäre der menschlichen Symbiosen hätte das - spannende!

- Thema dieser Szenenfolge sein können, [...]“" (Zeit 25.05.00, 42)

5. Mulighedsrum, M (possibility space (Fauconnier 1994: 92)), hvor sagsforholdene (endnu) ikke er realiseret i R, men har potentiale til at blive det. Inden for det opsatte rum $\mathrm{M}$ har sagsforholdene dog altid sandhedsværdien sand:

${ }^{M}$ Nichtdestoweniger, eine liberale Reformpolitik könnte, bei anhaltender politischer Stabilität, den Kapitalzufluss nach Russland vergrößern, den Wachstumsprozess stärken und den Ost-West-Handel stimulieren - und damit Demokratie und Marktwirtschaft in Russland festigen." (Zeit 08.06.00: 32)

6. Fiktionsrum, F (image space (Fauconnier 1994: 10ff)), hvor sagsforholdene optræder i en fiktiv verden og derfor ikke kan realiseres i R. Dog har sagsforholdene sandhedsværdien sand inden for F:

„Fie Geschichte scheint in einer mystisch-märchenhaften, untechnisierten Vorzeit zu spielen, in einer beseelten Landschaft, dem so genannten Otschtal. FAuch die Mitglieder der Familie Leghorn, die da im Tal des Flusses Otsch lebt, haben seltsame Namen. F Der Vater, der sich in eine gesichtslos bleibende Stadt davongemacht hat, heibt Caleb, sein Bruder Zack, seine Frau Rose Marie. ${ }^{F}$ Die beiden Töchter heißen Joa und Timpie." (Zeit 08.06.00: 53)

7. Konstitutivt rum, K (domain space (Fauconnier 1994: 31)), hvor sagsforholdene også har en anden epistemisk værdi end sagsforhold i realitetsrummet, idet man går ind $i$ andre regelsæt, teorier eller love, som derved bliver målestok for, hvad der holder inden for K. De nye 


\section{6}

regelsæt, teorier eller love er ikke nødvendigvis identiske med dem i $\mathrm{R}$ :

${ }^{{ }^{K}}$ Doch in der Politik geht es nicht nur um strategische Vernunft, sondern auch um Standorte, Pfründen und Aufträge." (Zeit 25.05.00: 1)

8. Evidentialisrum, E (believe space (Fauconnier 1994: 17)), hvor der opsættes et nyt mentalt rum, hver gang der skiftes til en mental repræsentation, der tilhører en anden end afsenderen, altså hver gang der er tale om et skift i evidentiel værdi. Sagsforholdenes sandhedsværdi bestemmes her ud fra den nye mentale repræsentations ophavsmand og ikke ud fra afsenderens opfattelse af virkeligheden, der normalt udgør det ideationelle udgangspunkt.

Da evidentialisrum er bestemt ud fra evidentiel værdi og omfatter en ny mental repræsentation, hvis virkelighedsopfattelse bliver den nye målestok for tilskrivningen af sandhedsværdier, vil det sige, at der inden for evidentialisrum også skal skelnes mellem forskellige epistemiske (og undertiden evidentielle) værdier, således at det er muligt at inddele sagsforholdene inden for evidentialisrummet i mindre mentale rum, f.eks. i realitetsrum eller irreale rum, hvis ophavsrum således bliver evidentialisrummet ${ }^{6}$ :

,${ }^{E}\left[{ }^{R 2}\right.$ Gewalt bringe mehr Erfolg als Verhandlungen, ${ }^{R 1}$ finden viele der Protestler; ${ }^{R l}$ sie führen den israelischen Rückzug aus der Sicherheitszone als Beweis dafür, ${ }^{E}{ }^{R 2}$ dass die Zionisten ,,müde " geworden seien.]" (Zeit 25.05.00: 9)

(Bernhardt/Knoth 1999: 32ff)

Teorien om mentale rum kan bruges til en ny definition af tekstuelle bistrukturer på den måde, at man kan gå ud fra, at hovedstrukturytringer tilhører ét bestemt mentalt rum, mens de ytringer, der tilhører et andet mentalt rum end hovedstrukturen, idet de har en anden epistemisk og/ eller evidentiel værdi, er bistrukturytringer. Hvilket rum hovedstrukturen tilhører, ved afsenderen normalt på forhånd, da han har et klart indtryk af, hvilken epistemisk og/eller evidentiel værdi hans budskaber har/skal have, og modtageren forsøger ligeledes allerede fra begyndelsen af teksten at opnå en forestilling om dette. Det sker allerede ved overskriften og de

6 Denne inddeling af evidentialisrum i egne epistemiske og evidentielle værdier nævner Fauconnier ikke selv. 
første ytringer, og især genreforventninger samt konteksten sætter en ramme op, der gør, at det ikke er vilkårligt, hvilket mentalt rum der opfattes som tilhørende hovedstrukturen. F.eks. forventer modtageren af avisartikler, at hovedstrukturen tilhører et realitetsrum, men der findes dog undtagelser. Tilhører hovedstrukturen et andet mentalt rum end realitetsrummet, bliver dette normalt klart for modtageren allerede gennem artiklens overskrift og de første ytringer, og modtageren tilpasser sin tekstreception til dette:

\begin{abstract}
"Cognitive assignments of topics, that is the global interpretation of a text by language users, do not take place when the language user has interpreted all the words and sentences of the whole text. Rather, the reader starts to make expedient guesses about the most probable topic(s) of a text, aided by the thematic signals of the writer. [...] As soon as we have heard a first sentence, we already try to guess what the overall or initial topic of a text or talk fragment may be. This is vitally important because the topic acts as a major control instance on the further interpretation of the rest of the text." (van Dijk 1988, 34)
\end{abstract}

Undertiden kan en teksts hovedstruktur tilhøre flere mentale rum på én gang. Dette er tilfældet, hvis hovedstrukturens "hovedrum" ikke samtidig er tekstens basisrum, altså hvis "hovedrummet" er inkluderet i et andet mentalt rum, som så at sige ligger uden om "hovedrummet". I disse tilfælde er også "hovedrummets" ophavsrum en del af hovedstrukturen.

Der opstår herudfra en hoved-/bistrukturdefinition, som ser således ud:

1. Hovedstruktur: Hovedstrukturytringer tilhører et eller evt. flere mentale rum.

2. Bistruktur: Bistrukturytringer tilhører et andet mentalt rum end hovedstrukturen.

Med denne nye hoved-/bistrukturdefinition løses Stutterheims problemer. For det første er tilhørsforholdet til et mentalt rum ikke teksttypeafhængigt, og der opstår således ikke problemer, hvis der ændres teksttype inden for samme tekst. For det andet er der i den nye definition en større plads til de dynamiske aspekter i tekstproduktion og -reception. Det er således kommunikationspartnerne selv, der inddeler tekstens sagsforhold i mentale rum, og det gør de på baggrund af ko- og kontekst, genre, interesser, verdensopfattelser osv. - og ikke på baggrund af et allerede fastlagt, overordnet kriterium såsom et quaestio. 


\section{Bistrukturers funktioner i teksten}

Stutterheim beskæftiger sig næsten udelukkende med teksters hovedstrukturer og kommer dermed ikke ind på, hvilke funktioner bistrukturerne har i helteksten (ud over at overbringe information naturligvis). Hvad er så at sige deres "kommunikativer Sinn", deres kommunikative mening, i det følgende i tyske avisartikler? Dette søges nu besvaret for at komme nærmere en forståelse af, hvor bistrukturer overhovedet optræder i tekster.

Tekster og ytringer er produkter af en kompleks handlingsplan fra afsenderens side. Afsenderen vil noget med sin tekst, og det er disse hensigter, han skal opfylde med sin tekst. Når modtageren skal erkende en given ytrings funktion i teksten, er det vigtigt for ham at gøre sig klart, at afsenderen til sin sproglige ytring knytter en hensigt. Og det er denne afsenderens hensigt, som modtageren har til opgave at erkende, når han reciperer ytringen. Her spiller begrebet illokution en vigtig rolle:

„Eine Äußerung verstehen heißt, ihren kommunikativen Sinn rekonstruieren zu können, d.h. festzustellen, welche illokutive Funktion die Äußerung in dem gegebenen Kontext haben soll.“ (Motsch 1986: 269)

Overordnet set vil afsenderens mål i avisartikler med både de enkelte ytringer og helteksten normalt rette sig mod en ændring i modtagerens verdensopfattelse. Det vil sige, at afsenderen med sin artikel søger at overbringe information til modtageren med det formål, at modtageren skal acceptere informationen og gøre den til en del af sit videnslager.

Ligesom alle andre ytringer spiller også bistrukturytringer en rolle i afsenderens hensigter med sin tekst, og de kommende afsnit vil undersøge følgende: Hvad er bistrukturytringernes funktioner i den givne tekst? Hvorfor ytres en bistrukturytring netop i den givne sammenhæng? Er der f.eks. tale om en konstatering eller et tankeeksperiment? Kort sagt, hvad skal bistrukturytringerne bruges til i den givne kommunikation?

I alle nedenstående eksempler tilhører hovedstrukturerne teksternes realitetsrum (R1), og det vil sige, at det er afsenderens fremstilling af hans egen virkelighedsopfattelse, der udgør tekstens flow, og at hovedstrukturen således udgøres af de sagsforhold, der har sandhedsværdien sand i forhold til det ideationelle udgangspunkt i tekstverdenen. Det vil sige, at ytringer, der tilhører alle andre mentale rum, altså generiske rum, hypotetiske rum, irreale rum, mulighedsrum, fiktionsrum, konstitutive rum og evidentialisrum, er bistrukturytringer, idet de bryder dette flow 
af sagsforhold, der indeholder afsenderens fremstilling af, hvad der er sandt i hans tekstverden.

Eksemplerne er uddrag fra tyske avisartikler ${ }^{7}$, og deres oprindelige ytringsnumre er bibeholdt, så det fremgår, hvor i artiklen ytringerne har stået.

\section{A. Generiske konstateringer}

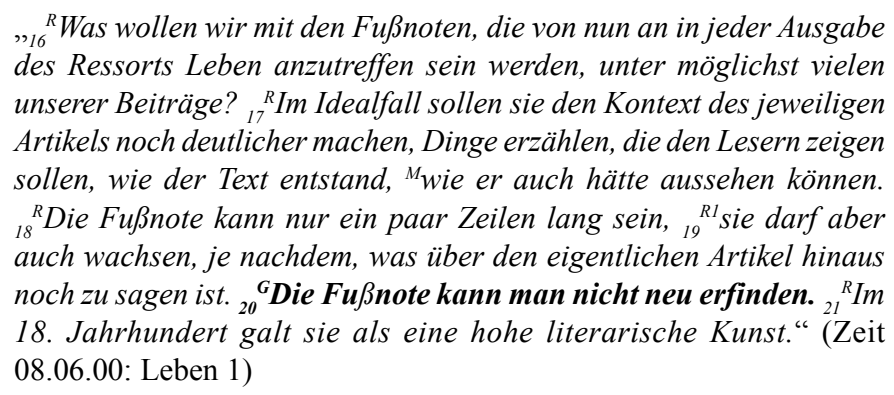

${ }_{16}{ }^{R}$ Was wollen wir mit den Fußnoten, die von nun an in jeder Ausgabe des Ressorts Leben anzutreffen sein werden, unter möglichst vielen unserer Beiträge? ${ }_{17}^{R} I m$ Idealfall sollen sie den Kontext des jeweiligen Artikels noch deutlicher machen, Dinge erzählen, die den Lesern zeigen sollen, wie der Text entstand, ${ }^{M}$ wie er auch hätte aussehen können. ${ }_{18}^{R}$ Die Fußnote kann nur ein paar Zeilen lang sein, ${ }_{19}{ }^{R 1}$ sie darf aber auch wachsen, je nachdem, was über den eigentlichen Artikel hinaus noch zu sagen ist. ${ }_{20}^{G}$ Die Fußnote kann man nicht neu erfinden. ${ }^{R} \mathrm{Im}$ 18. Jahrhundert galt sie als eine hohe literarische Kunst." (Zeit 08.06.00: Leben 1)

I dette eksempel er ytring 20 en bistrukturytring, idet den tilhører det generiske rum $\mathrm{G}$ og på denne måde går bort fra de øvrige sagsforholds partikulære hændelsesrække. Mens sagsforholdene i ytring 16-19 og 21 er specifikke sagsforhold bundet til én tid og én lokalitet, er sagsforholdet i ytring 20 derimod generisk. Sagsforholdet fremstilles ved hjælp af en atemporal brug af præsens som generelt gyldigt for mange tider og lokaliteter. Udsagnet er en generisk konstatering af, at man ikke kan genopfinde fodnoten på ny. Den findes nemlig allerede.

Agenterne, der ikke kan genopfinde fodnoterne, er ikke identificeret. Referensen er altså ikke fastlagt på bestemte personer: Sagsforholdet gælder klassen af mennesker generelt, hvilket understreges af brugen af det indefinitte pronomen man. Dette er med til at give sagsforholdet den almengyldighed, som er kendetegnet for generiske udsagn. Derudover bruges ofte også generisk interpreterbare substantiver med eller uden artikel til at udtrykke generiske konstateringer.

Generiske sagsforhold fremstilles i tekstverdenen som værende "mere sande" end sagsforholdene i tekstens realitetsrum. Idet de generiske konstateringer gælder for mange tider og lokaliteter, gælder de normalt også for netop de entiteter, der optræder i de specifikke sagsforhold (her fod-

7 De følgende analyser bygger på et korpus af tyve tyske avisartikler. 
noterne og Leben-redaktionens medlemmer i realitetsrummet). På denne måde kan de generiske sagsforhold samtidig være en karakteristik af entiteter i andre rum, normalt ophavsrummet (eller ophavsrummene, hvis der er flere overordnede ophavsrum), her realitetsrummet.

\section{B. Hypotetiske påstande}

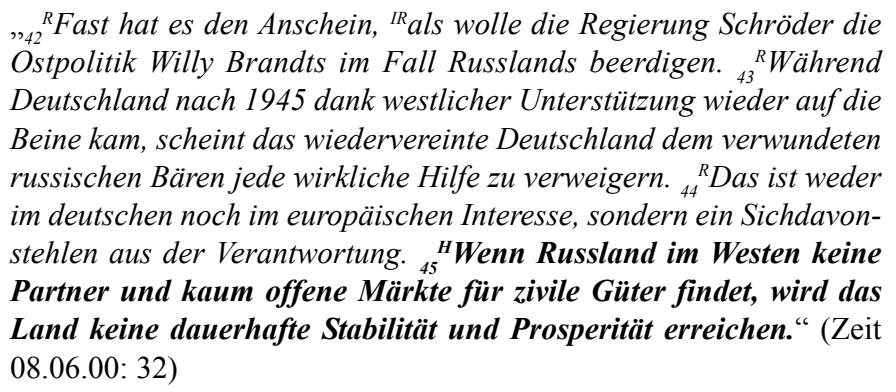

I dette eksempel tilhører bistrukturytring 45 et hypotetisk rum bestående af et hypotetisk betingelseskompleks med en betingelse og en følge. Hvis bare tekstverdenen ændres nok til, at betingelsen bliver opfyldt, vil følgen kunne realiseres i tekstens realitetsrum. Bistrukturytring 45 indeholder en hypotetisk påstand. En påstand (modsat en konstatering), fordi sagsforholdet ikke præsenteres som lige så sikkert, som hvis det havde tilhørt realitetsrummet. I realitetsrummet ville der ikke have været en betingelse, som først skulle opfyldes. Sagsforholdet præsenteres altså med en usikkerhedsfaktor; der er en forudsætning, som først skal være opfyldt. Men der er en stor sandsynlighed for, at sagsforholdet kan realiseres i realitetsrummet, og dette kommer til udtryk gennem brugen af indikativ i stedet for konjunktiv.

Ytring 45 er en beskrivelse af fremtidsudsigterne, hvis den nuværende tilstand, beskrevet i tekstens realitetsrum, opretholdes. Derudover udtrykker afsenderen her sin egen vurdering af Ruslands reale tilstand. Teksten er en kritik af det nuværende forhold mellem Tyskland på den ene side og Rusland på den anden side, en kritik af Tysklands dårlige behandling af Rusland.

Ud over i mange tilfælde at være fremtidsbeskrivelser fortæller hypotetiske påstande normalt også noget om den reale situation ${ }^{8}$ beskrevet $\mathrm{i}$

8 Situation skal her forstås som en samlet betegnelse for hændelser, handlinger, tilstande og egenskaber. 
realitetsrummet. Det kan være en karakteristik af, en vurdering af eller en kommentar til situationen i realitetsrummet. Det vil altså sige, at de hypotetiske påstande så at sige projicerer information op i ophavsrummet/ ophavsrummene.

„This highlights a general and distinctive property of counterfactuals 9 [...]; their power seems to lie instead in the inferences (produced through local space building) that they can project back to other spaces." (Fauconnier 1999: 119)

På denne måde siger de hypotiske påstande mange gange mere om sagsforholdene i ophavsrummet/ophavsrummene, end de opbygger deres egen fuldt specificerede verden.

\section{Irreale forestillinger}

${ }_{11}^{R}$ Seit 1985, dem eindrucksvollen Wahlsieg Johannes Raus mit 52,1 Prozent, geht es mit der SPD in Nordrhein-Westfalen kontinuierlich bergab. ${ }_{19}^{R}$ Konnte die Partei 1990 noch 50 Prozent der Wählerstimmen erringen, waren es 1995 nur noch 46 Prozent, ${ }_{20}{ }^{R}$ bei den Wahlen vor etwas weniger als zwei Wochen errang die Partei noch 42,8 Prozent. ${ }_{21}^{I R}$ Um diese Entwicklung aufzuhalten und umzukehren, müssten die Regierungsparteien alle Veränderungen und Erneuerungen, ${ }^{R}$ die die anderen Parteien nicht zu Unrecht gefordert haben und deren Ausbleiben die Zustimmung sinken ließ, ${ }^{\text {IR }}$ selbst auf dem Weg bringen. ${ }_{22}^{R} \mathrm{Cle-}$ ment muss sich dem künftigen Wähler schon jetzt und die ganze Legislaturperiode hindurch als erfolgreicher Regierungschef empfehlen." (FAZ 26.05.00: 3)

I dette tilfælde tilhører det meste af bistrukturytring 21 et irrealt rum. Ytringen beskriver, hvad regeringspartierne skal gøre i fremtiden for at bremse nedgangstiderne for partierne. Men da dette ikke synes sandsynligt, fremstilles sagsforholdet som ikke-realiserbart i tekstens realitetsrum, og sagsforholdet er således en irreal forestilling, et tankeeksperiment fra afsenderens side, hvilket markeres gennem brugen af konjunktiv II:

„Det hypotetiske betingelseskompleks ${ }^{10}$ fremstiller forbindelsen af betingelse/forudsætning og følge som noget irrealt [...]. Der anstilles altså

9 Fauconnier synes ikke at skelne mellem reale og irreale betingelseskomplekser.

10 Lauridsen og Poulsen opfatter hypotetiske betingelseskomplekser som basis for irrealis generelt. Man kan ifølge dem normalt ane en underforstået betingelse, også selv om denne ikke er udtrykt eksplicit (Lauridsen/Poulsen 1995: 236ff). 
et tankeeksperiment - det overvejes, hvad der kunne være indtruffet under andre omstændigheder. Bemærk, at der ikke - som ved eventualis [...]-tages stilling til, om betingelsen trods alt kan opfyldes; betingelsen og med den hele udsagnet fremstilles i den givne situation entydigt som ikke realisabel og dermed i strid med virkeligheden." (Lauridsen/ Poulsen 1995: 236)

Sagsforholdene står derfor i direkte modstrid med tekstverdenens realitet. Der er „kun“ tale om et tankeeksperiment fra afsenderens side. I sådanne forestillinger kan udtrykkes en stor mængde viden om ting, der ikke er sket:

„A significant part of our knowledge is usually expressed in subjunctive and „,contrary-to-fact“ conditional statements. We seem to have knowledge of what might have happened, of what would happen if certain conditions were realized, of what tendencies, faculties, or potentialities an object could manifest in suitable environments. And this, most of us would be inclined to say, is valid and significant, even though the possible events to which it seems to pertain may never become actual.“" (Chisholm 1946: 289)

Ud over at være tankeeksperimenter fortæller irreale forestillinger også noget om den reale, aktuelle situation i realitetsrummet. De er ofte karakteristikker af hele eller dele af situationer i realitetsrummet. Det vil altså sige, at de irreale forestillinger, på samme måde som de hypotetiske påstande, projicerer information op i ophavsrummet/ophavsrummene. Således siger også de irreale forestillinger mange gange mere om sagsforholdene i ophavsrummet/ophavsrummene, end de opbygger deres egen, fuldt specificerede verden for sig selv. Ytring 21 karakteriserer tilstandene i tekstens realitetsrum på den måde, at den indeholder afsenderens svar på regeringspartiernes problemer i realitetsrummet: Han beskriver, hvad han mener der skal til for at vende udviklingen. Ytring 21 indeholder derudover afsenderens kritik af de nuværende forhold for regeringspartierne, en kritik af, at de endnu ikke gør noget for at vende nedgangen.

\section{Mulighedsantagelser}

${ }^{R l}{ }_{8}$ Barak sagte, ${ }^{E 1}\left[{ }^{R 2}\right.$ er habe keine Angst vor Neuwahlen.] ${ }_{9}^{E 1}\left[{ }^{R 2}\right.$ Die Wähler würden jene bestrafen, die ihn daran hindern wollten, seine Mission zu erfüllen.] ${ }_{10}^{R I}$ In einer Erklärung seines Büros hieß es: ${ }_{11}^{E 2}{ }^{R 3}{ }^{3}$, Der Minister hat sich entschlossen, die Situation zu beenden, in der Minister Kabinettstühle wärmen und zugleich als Oppositionspo- 
litiker handeln. "] ${ }_{12}^{R I} Z$ war hatte er schon am Dienstag für den Fall seiner Niederlage die Bildung eines linken Minderheitskabinetts angekündigt, ${ }^{M}$ das mit der Duldung der zehn arabischen Abgeordneten regieren könnte. ${ }_{13}^{R I}$ Nach der Abstimmung wurde aber deutlich, dass die Kritiker in Baraks bisherigem Kabinett Neuwahlen verhindern wollen." (FAZ 08.06.00: 2)

I dette eksempel tilhører den sidste del af ytring 12 et mulighedsrum. Sagsforholdet i mulighedsrummet beskriver noget, som kunne være sket, hvis de rette betingelser havde været opfyldt. Barak havde bebudet en ny mindretalsregering, som i fremtiden kunne regere med hjælp fra de ti arabiske medlemmer af Knesset, hvis Barak led et nederlag endnu engang. Men betingelsen var altså, at Barak skulle lide et nederlag, og eftersom dette ikke skete, og betingelsen derfor ikke blev opfyldt, blev den nye mindretalsregering ikke nødvendig.

Der er således her tale om en mulighedsantagelse, en antagelse af noget, som kunne være sket, men som ikke skete, da de nødvendige betingelser ikke er eller var til stede:

„Konjunktiv II kan benyttes i udtryk, der angiver at noget kunne, burde, skulle ske eller kunne, burde, skulle være sket under betingelser, som ganske vist ikke er eller var til stede, men som på den anden side heller ikke er eller var umulige - såkaldt eventualis [...]. Det hypotetiske betingelseskompleks og dermed irrealis anes igen som grundlag, idet konstruktionerne kan opfattes som følger med underforstået betingelse. [...] Det irreale indhold er imidlertid afsvækket, for da betingelsen rent faktisk kunne virkeliggøres resp. kunne have været virkeliggjort, rykkes følgen også bort fra det helt umulige. Mens irrealis som nævnt fremstiller udsagnet som et rent tankeeksperiment, angiver eventualis, at selv om udsagnet ikke bliver/blev realiseret, kunne det dog realiseres/være blevet realiseret, hvis betingelserne var til stede - og det kunne de have været.“ (Lauridsen/Poulsen 1995: 242)

Man kan altså betragte eventualis som havende et underliggende hypotetisk betingelseskompleks, hvor

,[...] sætningen med eventualitetens konj. II betragtes som følge i et betingelseskompleks under tilføjelse af en stereotyp betingelse med indholdet ,hvis forholdene tillod $\operatorname{det}^{\star}$ [...].“ (Jørgensen bd. 3, 1992: 79)

At sagsforholdet ikke sker/skete, skyldes ikke, at sagsforholdet i sig selv er en umulighed, og det er her, mulighedsantagelser adskiller sig fra de irreale forestillinger. Sagsforholdet sker/skete ikke, fordi de nødvendige 
Ytring 31 og 32 er her bistrukturytringer, idet de tilhører et konstitutivt rum. Der er tale om konstitutive konstateringer, idet sagsforholdene beskriver den forestillingsverden, det regelsæt, som gælder for politikergenerationen efter Hitler: Magt er hverken mål i sig selv eller personlig ejendom. Magt skal retfærdiggøre sig gennem arbejde for demokrati, humanitet og social retfærdighed. Samtidig forklarer disse konstitutive konstateringer baggrunden for forholdene i realitetsrummet. De forklarer, hvorfor Kohl i 1982 var, som han var: Det var, fordi han netop var vokset op i den forestillingsverden, som hans politikergeneration levede i.

\section{G. Evidentielle inddragelser}

"Most important news events follow a standard procedure for asking the comments of important participants or prominent political leaders. The rationale for such a Verbal Reactions section is obvious. It allows journalists to formulate opinions that are not necessarily their own, but which nevertheless are objective because they have actually been stated. Of course, the selection of speakers and of quotations need not be objective." (van Dijk 1988: 55f)

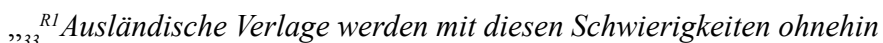
kaum in Berührung kommen, ${ }_{34}{ }^{R l}$ dazu sind die Lizenz-Einkäufer zu vorsichtig. ${ }_{35}^{E 1} I^{R 2}$, Um unsere jungen, frechen Bücher", $]^{R 1}$ sagt Hansjörg Weitbrecht, ${ }^{E 1}{ }^{R 2}$, ,schleichen die Verlagsleute wie die Katze um den heißen Brei.] ${ }_{36}^{E 1} I^{R 2}$ Aber sie trauen sich noch nicht. "I ${ }_{37}^{R 1}$ Und Chen Juns glänzende Augen verformen sich zu einem mitleidigen Blick: ${ }_{38}^{E 2} I^{R 3}$ "Es gibt bei uns eben Tabu-Themen wie den Tod, ${ }_{39}^{E 2} I^{R 3} d a s$ wollen unsere Kinder nicht. " ${ }_{40}{ }^{R I}$ Also wieder Detektivgeschichten und Abenteuerromane mit schönen Bildern." (SZ 04.09.00: 18)

I ovenstående eksempel er det meste af ytring 35, hele ytring 36,38 og 39 bistrukturytringer, idet de tilhører evidentialisrum. Dette sker ved et skift fra realitetsrummet, som tilhører afsenderens mentale repræsentation, til henholdsvis Hansjörg Weitbrechts og Chen Juns mentale repræsentationer. En tekst kan således indeholde forskellige ophavsmænds udsagn:

"En tekst kan betragtes ud fra et „ophav“ssynspunkt, altså ud fra det synspunkt, hvem de enkelte dele af teksten, udsagn eller tanker, stammer fra, og en analyse af denne art vil - med mere eller mindre sikker afgrænsning - føre til en opdeling i to slags tekststykker: stykker, som indeholder forfatterens eller fortællerens egen tale eller egne tanker, her kaldet „forfatter-tekst", og stykker, som er forfatterens gengivelse af andres tale eller tanker [...], her betegnet som "referat-tekst"." (Jørgensen 1992, bd. 3: 100) 
146

I tekstens realitetsrum beskriver afsenderen de udenlandske forlags situation i Kina. Dernæst skiftes til Hansjörg Weitbrechts mentale repræsentation, hvor der direkte gengives, hvad han har sagt:

„Ved direkte tale forstås et citat, som er eller gør krav på at være en

ordret gengivelse af et udsagn [...].“ (Lauridsen/Poulsen 1995: 245)

Her fremstiller teksten altså udsagnene som værende en ordret gengivelse af oprindelige udsagn. Den oprindelige udformning bibeholdes altså, eller rettere sagt: fremstilles som værende bibeholdt. Teksten fortæller, at Hansjörg Weitbrecht faktisk har sagt, at forlagene kredser om de nye, vovede bøger som katten om den varme grød, men at de ikke tør slå til. Den direkte gengivelse markeres med brugen af citationstegn. Derefter skiftes der i ytring 37 kort tilbage til afsenderens mentale repræsentation, hvorefter en tredje mental repræsentation, nemlig Chen Juns, dukker frem i ytring 38 og 39. Også Chen Juns udsagn fremstilles som værende en ordret gengivelse markeret ved hjælp af citationstegn. Han har faktisk sagt, at der findes tabuemner såsom døden, og at børnene ikke vil læse om det. I ytring 40 skiftes der igen tilbage til afsenderens egen mentale repræsentation.

Bistrukturytringerne 35, 36, 38 og 39 indeholder således evidentielle inddragelser, altså inddragelser af information, som kommer fra andre mentale repræsentationer end afsenderens. Disse inddragelser er med til at beskrive og uddybe de situationer, som tilhører tekstens realitetsrum, nemlig at forlagene ikke tør tage de nye, frække bøger, og at der findes tabuemner, som børnene ikke vil høre om.

${ }_{22}^{R 1}$ Bei der SPD versucht sich einstweilen Generalsekretär Franz Mün-
tefering als Besänftiger. ${ }_{23}^{R I}$ Doch auch er ist offenbar ratlos. ${ }_{24}^{E} I^{R 2}$ Es
gebe für die Situation keinen idealen Lösungsansatz, ${ }^{R 1}$ schreibt er in
einem Brief an alle Gliederungen der Partei. ${ }_{25}^{R I}$ Dann wiederholt er
das, was schon oft gesagt wurde: ${ }_{26}^{E} I^{R 2}$ An der Preisexplosion bei Heizöl
und Benzin seien die Verknappung des Angebots aufden Rohölmärk-
ten sowie die Dollarstärke schuld.] ${ }_{27}^{E} I^{R 2}$ Das internationale Marktge-
schehen könne aber nicht durch eine nationale Steuerpolitik neutra-
lisiert werden.J ${ }_{28}^{R I}$ Der Abbau der Staatsverschuldung lassen dafür keine
Luft. " (SZ 15.09.00:2)

Her tilhører en del af ytring 24, hele ytring 26 samt hele ytring 27 et evidentialisrum. Sagsforholdene i dette evidentialisrum præsenteres ikke som værende direkte, ordrette gengivelser af de oprindelige udsagn. De 
er derimod indirekte gengivelser, i dette tilfælde af, hvad Müntefering har skrevet $\mathrm{i}$ et brev:

„INDIREKTHEITSKONTEXTE sind Kontexte, also Verwendungszusammenhänge, in denen der Sprecher ein Stück propositionalen Wissens nicht unmittelbar als für ihn selbst zum Sprechzeitpunkt aktuelles Wissen anspricht, sondern es wiedergibt, indem er sich auf eine andere Quelle rückbezieht. Diese andere Quelle ist

a) der Sprecher selbst oder ein anderer Sprecher, und zwar zu einem anderen Sprechzeitpunkt als dem gerade aktualen Sprechzeitpunkt oder in einer nur gedachten Äußerungssituation,

b) eine Person oder ein als denkfähig betrachtetes Wesen, zu dessen Einstellungen, Gedanken und Gefühlen der Sprecher - wie auch immer - Zugang hat.“ (Zifonun et al. 1997: 1753)

I disse indirekte gengivelser, der ofte markeres ved hjælp af brugen af konjunktiv, tager afsenderen på trods af brugen af konjunktiv ikke nødvendigvis afstand fra sagsforholdet, sådan som f.eks. Jørgensen (1992) mener det:

"Også i indirekte tale er konjunktiven tegn for en vis afstand fra "virkeligheden", nemlig således, at forfatteren ved anvendelse af konjunktiv i gengivelsen af en persons udsagn eller tanke til en vis grad tager afstand fra det sagte eller tænkte, ikke i al almindelighed, men for sit eget vedkommende; han siger med konjunktiven: jeg garanterer ikke for rigtigheden af det refererede." (Jørgensen 1992, bd. 3: 107)

Derimod markerer afsenderen "bare" over for modtageren, at der her er tale om en anden mental repræsentation end hans egen:

"Når der bruges konjunktiv i indirekte tale og citationstegn i direkte tale, behøver det ikke være, fordi afsenderen vil lægge afstand til det ytrede sagsforhold, sådan som mange nok ville opfatte det. Det er derimod en måde, hvorpå afsenderen formelt set tydeliggør, at der skiftes til en anden mental repræsentation. Om afsenderen er enig med den nye mentale repræsentations opfattelse af virkeligheden eller ej, er et andet spørgsmål." (Bernhardt/Knoth 1999: 70)

Det står således som udgangspunkt åbent, om afsenderen kan tilslutte sig udsagnet eller ej:

„In Indirektheitskontexten lautet die Verbindlichkeitsqualität für (wiedergegebene) Aussagesätze:

Ich, Sprecher $\mathrm{S}_{2}$, sage, daß $\mathrm{S}_{1}$ (der Sprecher der Originaläußerung) sagt, $\mathrm{da} \beta \mathrm{p}$, aber ich lasse offen, ob ich sage, daß $\mathrm{p}$. 
148

Dagegen signalisiert der Sprecher in Behauptungskontexten ${ }^{11}$

eindeutig ,ich sage, daß p“.“ (Zifonun et al. 1997: 1762)

Dog kan modtageren som regel læse ud af ko- og konteksten, om afsenderen kan tilslutte sig udsagnet.

Det er ved både direkte og indirekte gengivelser vigtigt at være opmærksom på, at det oprindelige udsagns illokution, altså den illokution, som det gengivne udsagn havde i den daværende kommunikationssituation, ophæves i gengivelsen og tildeles sin egen illokution alt efter den gengivende afsenders hensigt med gengivelsen (Brünner 1991: 3).

Evidentielle inddragelser kan benyttes til at bringe oplysninger om de situationer, der optræder i de øvrige sagsforhold, ofte i evidentialisrummenes ophavsrum, normalt realitetsrummet. På denne måde projicerer de information op i ophavsrummet/-rummene, som beskrives, uddybes, kritiseres eller lignende.

De evidentielle inddragelser kan bruges til at inddrage folk, som er eksperter på et område. Disse eksperter kan give "objektive" informationer om de situationer, der optræder i de øvrige sagsforhold. Dette kan være oplysninger, som avisartiklens afsender enten ikke havde i forvejen, og som han derfor fik af eksperterne, eller det kan være oplysninger, som han godt kendte til, men som han får underbygget gennem ekspertudsagnene. På denne måde kan afsenderen udtrykke andres og/eller egne holdninger. Når afsenderen vil udtrykke egne holdninger, kan han bruge de evidentielle inddragelser til at "tale" indirekte gennem en anden person og dermed slippe for ansvaret:

\begin{abstract}
„Indem der aktuelle Hörer gleichsam zum Ohrenzeugen gemacht wird, wird er über die Äußerung scheinbar unmittelbar informiert. So kann sie der aktuelle Sprecher thematisieren oder problematisieren, er kann durch Redewiedergaben eigene Behauptungen belegen oder stützen und etwas sagen, ohne dies selbst verantworten zu müssen.“(BRÜNNER 1991, 7) $)^{12}$
\end{abstract}

På denne måde bliver det f.eks. muligt at kritisere en situation eller en person "på andres regning". Derudover kan inddragelserne også bruges til at inddrage holdninger, hvis ophavsmand ikke identificeres nærmere, men som tilhører folk generelt.

11 Behauptungskontexte er udsagn, der tilhører afsenderens mentale repræsentation.

12 Dette citat indeholder en beskrivelse af direkte gengivelse, men passer også til indirekte, med undtagelse af ordet unmittelbar, der i så fald skal erstattes med mittelbar. 


\section{H. Reale konstateringer}

Det er ifølge denne artikels definition således, at alle ytringer, der tilhører et eller flere bestemte mentale rum (dog ofte kun realitetsrummet (R1)) er hovedstrukturytringer. Dette kan dog diskuteres. Eftersom det er tekstens hovedstruktur, der udgør tekstens rygrad, dens main line, er det plausibelt at gå ud fra, at det også er indeholdet af disse ytringer, der ifølge van Dijks makrostrukturteori bliver ført videre til tekstens forskellige makroniveauer i modtagerens makrostruktureringsproces. Nogle af ytringerne vil kun "overleve" på første abstraktionsniveau, mens de fleste dog med stor sandsynlighed vil blive ført videre op i hierarkiet til de højere abstraktionsniveauer, og nogle vil endda til sidst udgøre tekstens mest overordnede makrostruktur (teksttemaet). Indholdet af bistrukturytringerne vil derimod normalt være det samme som det, der bliver sorteret fra eller stærkt omformuleret i makrostruktureringsprocessen, og dette er tilfældet for visse typer ytringer, der tilhører det/de samme mentale rum som hovedstrukturen (jvf. undersøgelse i Bernhardt/Knoth 1999: 141ff). Definitionen af hoved- og bistrukturer kan således udbygges til:

1) Hovedstruktur: Hovedstrukturytringer tilhører et eller evt. flere mentale rum og overføres til makroniveau.

\section{2) Bistruktur:}

a. Bistrukturytringer tilhører et andet mentalt rum end hovedstrukturen.

b. Bistrukturytringer tilhører det/de samme mentale rum som hovedstrukturen, men overføres ikke til makroniveau.

I de teksteksempler, som denne artikel anvender, hvor alle hovedstrukturerne tilhører realitetsrummet (R1), vil det sige, at ikke alle ytringer, der tilhører realitetsrummet, nødvendigvis er hovedstrukturytringer.

\footnotetext{
${ }^{R I}{ }_{6}$ Obwohl es noch Monate dauern wird, bis das entsprechende Gesetz fertig gestellt ist, gilt Barak als politisch geschwächt. ${ }_{7}{ }^{R I}$ Seine Niederlage erschwert die Gespräche mit den Palästinensern und Syrien. ${ }_{8}^{R I}$ Barak sagte, ${ }^{E 1}{ }^{R 2}$ er habe keine Angst vor Neuwahlen.] ${ }_{9}^{E 1}{ }^{R 2}$ Die Wähler würden jene bestrafen, die ihn daran hindern wollten, seine Mission zu erfüllen. ${ }_{10}{ }^{R 1}$ In einer Erklärung seines Büros hie $\beta$ es: ${ }_{11}^{E 2}\left[{ }^{R 3}{ }_{\text {,Der Mini- }}\right.$ sterpräsident hat sich entschlossen, die Situation zu beenden, in der Minister Kabinettstühle wärmen und zugleich als Oppositionspolitiker handeln. "] ${ }_{12}^{R I} Z$ war hatte er schon am Dienstag für den Fall seiner Niederlage die Bildung eines linken Minderheitskabinetts angekündigt, ${ }^{M}$ das mit der Duldung der zehn arabischen Abgeordneten regieren könn-
} 
te. ${ }_{13}^{R l}$ Nach der Abstimmung wurde aber deutlich, dass die Kritiker in Baraks bisherigem Kabinett Neuwahlen verhindern wollen. ${ }_{14}^{E 3} R^{R 4}$ ,Niemand hat Interesse an Neuwahlen ", ${ }^{R I}$ sagte der Minister Yischai, der Vorsitzende der orientalischen Schas-Partei.“ (FAZ 08.06.00: 2)

I dette eksempel kan første del af ytring 8 , hele ytring 10 samt sidste del af ytring 14 betragtes som bistrukturytringer, fordi de er appendiks til andre bistrukturytringer. Et appendiks er her en ytring, der er et tillæg til en eller flere andre ytringer; et tillæg, der indeholder yderligere information, som supplerer indholdet af den eller de ytringer, som det lægger sig til. Fordi et appendiks først og fremmest supplerer andre ytringer, er det disse andre ytringer, der er afgørende for, om appendikset tilhører hovedstrukturen eller er en bistruktur. Hvis den eller de ytringer, som appendikset lægger sig til, er en bistruktur, er appendikset det nødvendigvis også.

Første del af ytring 8 er her et appendiks til det efterfølgende sagsforhold i evidentialisrummet E1, som nødvendigvis er en bistrukturytring, idet tekstens hovedstruktur kun tilhører R1. Ytring 10 er et appendiks til sagsforholdene i ytring 11, som tilhører evidentialisrummet E2, og som derfor også er en bistrukturytring. Sidste del af ytring 14 er en bistrukturytring, fordi den er et appendiks til det foregående sagsforhold i E3.

Eftersom disse appendices, der alle tilhører R1 og derfor er kandidater til at tilhøre tekstens hovedstruktur, lægger sig til bistrukturytringer, kan de selv betragtes som bistrukturytringer. Men appendices har dog mindst én anden funktion ud over at være appendiks ${ }^{13}$. I dette teksteksempel er de ovennævnte bistrukturytringer som nævnt appendices til forskellige evidentialisrum. Disse appendices har derudover den funktion, at de situerer evidentialisrummene, så det bliver klart for avisartiklens modtager, hvem der har sagt hvad og i hvilken situation:

„Dem aktuellen Hörer muß die wiedergegebene kommunikative Handlung als eine solche verdeutlicht werden, und sie muß so situiert werden, daß wiedergegebener Sprecher, Hörer und Situation klar werden.“ (Brünner 1991: 3)

og

„Im Kontext werden Redewiedergaben häufig durch Redeeinleitungen
- oder besser: Redesituierungen - kenntlich gemacht, in denen z.B.

13 Der kan dog sættes spørgsmålstegn ved, om det at være appendiks overhovedet er en funktion i denne artikels forstand. 
Sprecher, kommunikativer Handlungstyp oder Umstände der Äußerung genannt werden.“ (Brünner 1991: 6)

${ }_{10}{ }^{R I}$ Den Bürgern ist der smarte, gut aussehende Mittvierziger Rutelli zweifellos symphatischer als der kleine, stets etwas hölzern und besser-

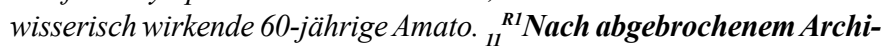
tektstudium begann Rutelli seine politische Karriere bei der Radikalen Partei, wechselte dann zu den Grünen und landete schließlich bei der Partei der Demokraten. ${ }_{12}^{R 1}$ Als Grüner war er zu Beginn der neunziger Jahre kurz Umweltminister. ${ }_{13}^{R 1} 1993$ wurde er zum römischen Bürgermeister gewählt, ${ }_{14}{ }^{R 1}$ vier Jahre später ließ $\beta$ er sich - ein rauschender Wahlerfolg - im Amt bestätigen. ${ }_{15}^{R 1}$ In Rom, der ewigen, beinahe unregierbaren Stadt, hat er zumindest auf dem Verkehrssektor

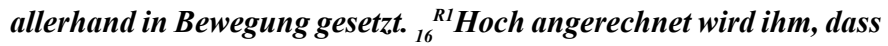
im Heiligen Jahr selbst am Weltjugendtag mit einer Rekordbeteiligung von zwei Millionen jungen Leuten das große Chaos ausblieb. ${ }_{17}^{R l} S O$ gilt Rutelli, den sie auch ${ }^{E 1}{ }^{R 2}{ }^{2}$,Clintonino " ${ }^{R 1}$ (kleiner Clinton) nennen, als ein sachpolitisch orientierter Typ, ein Erneuerer. ${ }_{18}{ }^{R I}$ Hingegen hängt Regierungschef Amato noch der Geruch der alten Republik in den

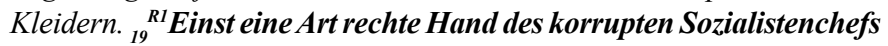
Bettino Craxi, diente er verschiedenen Regierungen als Minister und Ministerpräsident. ${ }_{20}^{R I}$ Der angesehene Universitätsprofessor, auch ${ }^{E 1}{ }^{R 2}$, ,Doktor Spitzfindig "] genannt, verkörpert eher die traditionelle italienische Poltik, ${ }^{K}$ in welcher der Machterhalt, mit welchen Winkelzügen auch immer, als Wert an sich gilt." (SZ 04.09.00: 4)

I dette eksempel kan ytringerne 11-16 samt 19 betragtes som bistrukturytringer, fordi de indeholder information om fortiden. Dette sker ved et skift fra sagsforhold, der tilhører en bestemt tid i hovedstrukturen, til sagsforhold, der fremstilles som tilhørende en tid, der ligger forud for tiden i hovedstrukturen. Hvis hovedstrukturen eksempelvis tilhører nutiden (i bred forstand), som den ofte gør i avisartikler, er følgende tilfældet for hovedstrukturytringernes tidslige indordning:

„Aktzeit, Sprechzeit und Betrachtzeit fallen in der Gegenwart zusammen.” (Helbig/Buscha 2001: 130) ${ }^{14}$,

14 Aktzeit er handlingstidspunktet, dvs. det tidspunkt, hvor den beskrevne handling, hændelse eller tilstand ifølge tekstverdenen oprindeligt er udført/foreligger. Sprechzeit er taletidspunktet, dvs. det tidspunkt, som udsagnet faktisk ytres på af afsenderen. Betrachtzeit er betragtningstidspunktet, dvs. det tidspunkt eller perspektiv, som afsenderen ser handlingen, hændelsen eller tilstanden på (Helbig/Buscha 1993: 144). Analysen af tid i handlingstidspunkt, betragtningstidspunkt og taletidspunkt stammer fra Reichenbach 1947, der analyserer tid i engelsk og dog bruger betegnelsen point of event om handlingstidspunkt, point of reference om betragtningstidspunkt og point of speech om taletidspunkt. 
152

hvor handlingstidspunktet, taletidspunktet (i avisartikler drejer det sig om afsenderens skrivende stund) og betragtningstidspunktet altså er overlappende. Der sker et skift fra hovedstruktur til bistruktur, hvis der sker en forandring bagud i tid, således at:

„Aktzeit und Betrachtzeit sind identisch, beide liegen vor der Sprechzeit.“ (Helbig/Buscha 2001: 133).

Her består skiftet $i$, at handlingstidspunktet og betragtningstidspunktet nu ligger forud for taletidspunktet. Det vil sige, at det altså drejer sig om en handling, hændelse eller tilstand samt et betragtningstidspunkt, der ligger i fortiden i forhold til afsenderens skrivende stund. I ovenstående eksempel er tekstens hovedstruktur nutidig. I ytring 11-16 skiftes der til en fortidig handling og et fortidigt betragtningstidspunkt, og der skiftes således fra hovedstrukturytring til bistrukturytringer. Her hører modtageren om Rutellis fortid på en måde, som beskriver, at Rutelli i lang tid har været populær. Dette er med til at forklare Rutellis nuværende popularitet som beskrevet i hovedstrukturens sagsforhold. I ytring 17 og 18 skiftes der tilbage til hovedstrukturens nutidige beskrivelse af, hvordan Rutelli og Amato opfattes i afsenderens skrivende stund. Dernæst skiftes der igen til et fortidigt sagsforhold, denne gang om Amatos fortid.

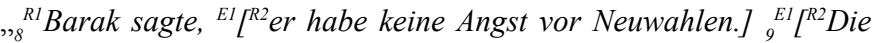
Wähler würden jene bestrafen, die ihn daran hindern wollten, seine Mission zu erfüllen.] ${ }_{10}^{R l}$ In einer Erklärung seines Büros hieß es: ${ }_{11}^{E 2}{ }^{R 3}$, ,Der Ministerpräsident hat sich entschlossen, die Situation zu beenden, in der Minister Kabinettstühle wärmen und zugleich als

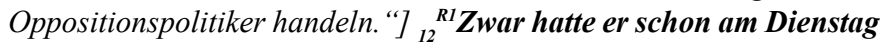
für den Fall seiner Niederlage die Bildung eines linken Minderheitskabinetts angekündigt, ${ }^{M}$ das mit der Duldung der zehn arabischen $A b$ geordneten regieren könnte. ${ }_{13}^{R I} N a c h$ der Abstimmung wurde aber deutlich, dass die Kritiker in Baraks bisherigem Kabinett Neuwahlen verhindern wollen." (FAZ 08.06.00: 2)
}

En teksts hovedstruktur kan selv tilhøre fortiden, således at handlingstidspunkt og betragtningstidspunkt ligger før taletidspunktet. Er dette tilfældet, kan bistrukturer alligevel godt indeholde information om fortiden. Dette er tilfældet, hvis handlingstidspunktet tager et yderligere skridt tilbage $i$ fortiden og på denne måde ligger før betragtningstidspunktet:

„Aktzeit liegt vor Betrachtzeit, Betracht- vor Sprechzeit.“ (Helbig/ Buscha 2001: 136) 
I dette ovenstående eksempel beskriver tekstens hovedstruktur en situation, som ligger forud for afsenderens her og nu. I ytring 12 tages der dog et skridt yderligere tilbage i tid, og ytring 12 kan således betragtes som en bistrukturytring. Ehud Barak havde allerede inden hovedstrukturens fortidige handling taget nogle forbehold, og disse forbehold er således "før-fortidige".

Sådanne fortidige informationer i bistrukturer kan bruges til at beskrive, hvorfor sagsforholdene i hovedstrukturerne er, som de er på hovedstrukturens tidspunkt. Det drejer sig altså om situationer, som har relevans og konsekvens for sagsforholdene i tekstens hovedstruktur. Ligeledes kan sagsforhold, der indeholder information om fremtiden og på denne måde også bevæger sig væk fra tiden i hovedstrukturen, være bistrukturer.

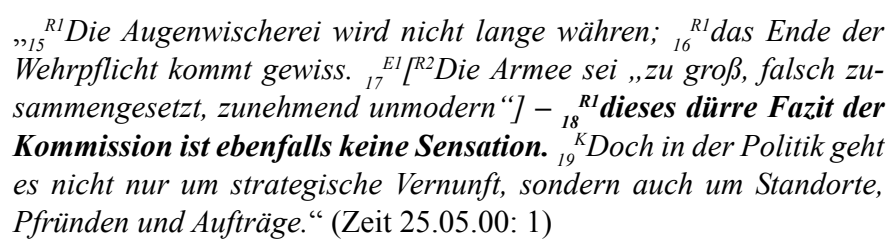

I dette eksempel kan ytring 18 betragtes som en bistrukturytring, fordi den er en afsenderkommentar. Ytring 17 indeholder kommissionens udsagn om, at Tysklands hær er i dårlig stand. Dette udsagn kommenteres i ytring 18 af avisartiklens afsender, som mener, at konklusionen ikke er en sensation. Denne kommentar står for afsenderens egen regning, og dens subjektive indhold falder uden for hovedstrukturen, som består af en mere objektivt præsenteret situationsrække - det vil sige, at afsenderen normalt præsenterer sagsforholdene i hovedstrukturen som værende faktiske situationer.

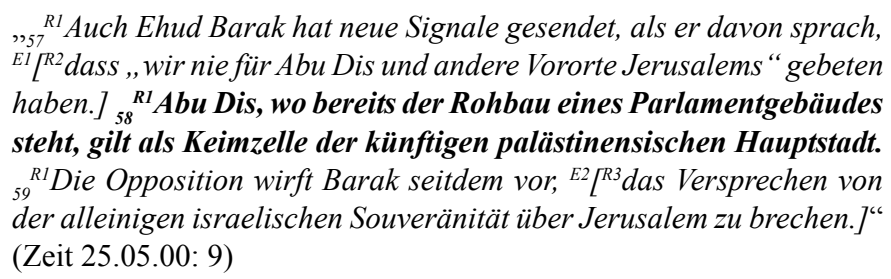

Her kan ytring 58 betragtes som en bistrukturytring, fordi den indeholder baggrundsinformation. I ytring 57 nævnes det, at Ehud Barak ikke har interesseret sig for Abu Dis eller andre forstæder til Jerusalem. Ytring 58 indeholder en baggrundsinformation om netop Abu Dis: Abu Dis er yderst 


\section{4}

vigtig for en fremtidig palæstinensisk hovedstad. Dette nævnes her for at lette modtagerens fortolkning af de foregående og efterfølgende sagsforhold i teksten. Modtageren bliver nu bedre i stand til at forstå, hvorfor Abu Dis spiller en central rolle for palæstinenserne. Herigennem forstås det ligeledes bedre, hvorfor Barak har sendt nye signaler via sin udtalelse om Abu Dis.

Ytringer med baggrundsinformation kan betragtes som bistrukturytringer, fordi der springes væk fra en situationsrække, der optræder i tekstens hovedstruktur. I dette tilfælde beskriver ytringen i hovedstrukturen, at Ehud Barak har udsendt nye signaler. Her forlades hovedstrukturen imidlertid, da afsenderen, for at sikre sig, at modtageren forstår vigtigheden i Baraks udmelding, i ytring 58 informerer modtageren om, hvad Abu Dis overhovedet er; Abu Dis spiller en hovedrolle i planerne om en ny, palæstinensisk hovedstad.

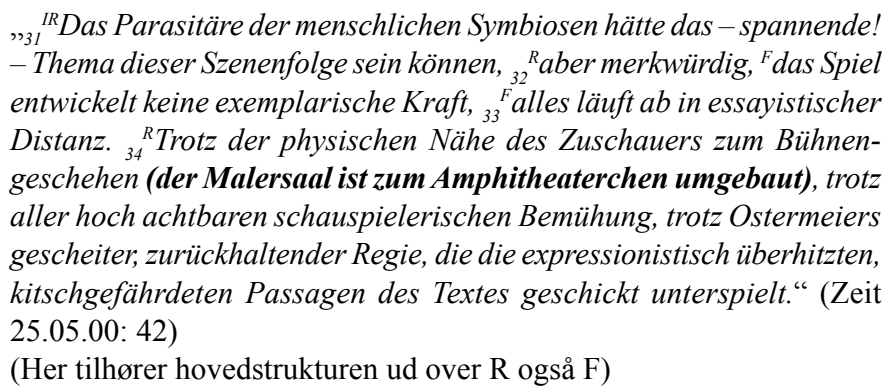

I dette eksempel kan en del af ytring 34 betragtes som en bistrukturytring, idet den indeholder en sidebemærkning. Med sidebemærkning menes, at der så at sige indskydes en bemærkning, der falder uden for den hovedlinje, som der er på det givne sted i teksten. Der kommer således en slags ophold, hvor teksten begiver sig ud ad et sidespor for at tilføje en information, der kan være vigtig at have med, men som ikke er nødvendig for forståelsen og fortolkningen af tekstens øvrige ytringer. Dette sker ved, at der "fra sidelinjen" tilføjes ekstra information. Sidebemærkninger fungerer som en slags parentes, men dette gør dog ikke nødvendigvis informationen irrelevant af den grund.

I dette ovenstående tekststykke, som er et uddrag fra en anmeldelse af et teaterstykke, der opføres i malersalen i Das Deutsche Schauspielhaus i Hamburg, fortæller hovedstrukturen, hvordan publikum sidder tæt på scenen. Det indskydes herefter, at malersalen er ombygget til et lille 
amfiteater. Denne information er interessant at få med, men falder så at sige uden for tekstens drive og er ikke en nødvendighed for modtageren at få at vide for at forstå beskrivelsen af, at publikum sidder tæt på scenen.

Baggrundsinformationer og sidebemærkninger kan ved første øjekast virke ens. Dette er dog ikke tilfældet. Baggrundsinformation omhandler baggrunden for en eller flere situationer, således at modtageren får hjælp til sin forståelse og fortolkning af disse. Baggrundsinformation indeholder således information, som afsenderen mener er nødvendig for modtagerens tekstreception, og som afsenderen er i tvivl om tilhører modtagerens pragmatiske viden. Baggrundsinformationerne letter således modtagerens forståelse af tekstens øvrige sagsforhold. Med sidebemærkninger indskydes der derimod information, der ikke primært er nødvendig for modtagerens forståelse og fortolkning af tekstens øvrige sagsforhold. Sidebemærkninger indskyder derimod anden information, som selvfølgelig er relevant, da den ellers normalt ikke ville forekomme (jvf. Grices relevansmaksime), men som er en slags ophold, hvor der hurtigt tilføres ekstra information, der er interessant, men ikke nødvendig for modtagerens forståelse af tekstens øvrige ytringer.

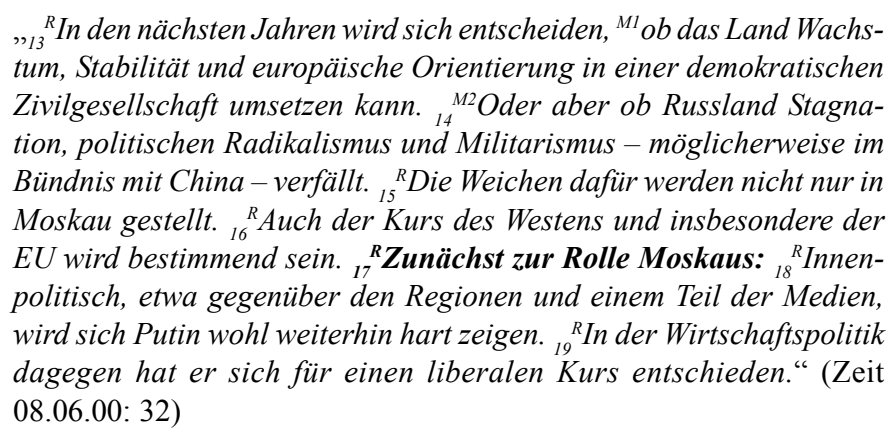

Her kan ytring 17 opfattes som en bistrukturytring, fordi den er en tekstorganisator og dermed uden for hovedstrukturens situationsrække. Afsenderen har før ytring 17 beskrevet, at der er to faktorer, som har indflydelse på Ruslands udvikling. Afsenderen vil derefter begynde med at beskrive den ene faktor, nemlig Moskva, og dette viser han over for modtageren ved hjælp af ytring 17's metakommunikative indhold. Ytring 17 markerer, hvilket indhold de følgende ytringer vil have - de vil beskrive, hvilken rolle Moskva spiller i den givne situation. Således er ytring 17 altså en 
tekstorganisator, som ved hjælp af sit metakommunikative indhold leder modtageren over i en ny beskrivelse.

Hvis tekstens hovedstruktur tilhører et eller flere andre mentale rum end realitetsrummet, gælder ovennævnte funktioner, appendiks, information om fortid og fremtid i forhold til hovedstrukturen, afsenderkommentar, baggrundsinformation, sidebemærkning og tekstorganisator, også for sagsforholdene i disse andre mentale rum ved inddelingen $i$ henholdsvis hoved- og bistrukturer.

Det skal til sidst nævnes, at det er vigtigt at være opmærksom på, at bistrukturer kan have flere funktioner på én gang. Således kan information om fortiden samtidig være en baggrundsinformation, en hypotetisk påstand kan samtidig være information om fremtiden osv.

\section{Sammenfatning}

Tekstuelle bistrukturer skal ikke forstås som, at de indeholder mindre vigtig information end tekstens hovedstruktur. Bistrukturer er udelukkende nogle, der præsenteres som faldende uden for tekstens flow, men dette er ikke ensbetydende med, at de ikke er relevante.

Denne artikel har foreslået en ny definition af tekstuelle bistrukturer. Med Fauconniers teori om mentale rum er det muligt at lave en klar skelnen mellem sagsforholdene i de mentale rum, der tilhører hovedstrukturen, og dem, der udgør bistrukturer. Hovedstrukturytringer er de ytringer, der tilhører et eller evt. flere bestemte mentale rum, samtidig med at de bliver overført til makroniveau. Hvilke(t) rum dette/disse er, får modtageren allerede fra starten af teksten et klart indtryk af. Bistrukturer udgøres derimod af de ytringer, der tilhører et andet mentalt rum end hovedstrukturen. Derudover kan bistrukturytringer tilhøre det eller evt. de samme mentale rum som hovedstrukturen, samtidig med at de ikke overføres til makroniveau.

Tilhørsforholdet til et bestemt mentalt rum er i første omgang bestemmende for, hvilken funktion en given bistrukturytring har i en tekst. Således kan bistrukturer, hvis hovedstrukturen tilhører realitetsrummet (R1), være generiske konstateringer, hypotetiske påstande, irreale forestillinger, mulighedsantagelser, fiktionsbeskrivelser, konstitutive konstateringer eller evidentielle inddragelser. I anden omgang kan bistrukturerne underordnet have andre funktioner samtidig såsom kritik, karakteristik 
osv. Også reale konstateringer kan være bistrukturer, selv om hovedstrukturen tilhører tekstens realitetsrum (R1). Dette er tilfældet, når der er tale om appendices, informationer om andre tider end den, som hovedstrukturen tilhører, afsenderkommentarer, baggrundsinformationer, sidebemærkninger og tekstorganisatorer.

\section{Referencer}

Avisartikler: Frankurter Allgemeine Zeitung (FAZ), Süddeutsche Zeitung (SZ) og Die Zeit (Zeit).

Bernhardt, Lise \& Knoth, Tine Woergaard 1999: Den mentale rumvandring. Et studie $i$ mental spaces og deres forhold til kohoesion og kohorens. Specialeafhandling, Københavns Universitet.

Bernhardt, Lise \& Knoth, Tine Woergaard 2000: Den mentale rumvandring. Refleksioner over mental spaces og deres forhold til kohæsion og kohærens. In Funktionelle Fodnoter 1-11. Dansk Funktionel Grammatik, Københavns Universitet, København.

Bernhardt, Lise \& Knoth, Tine Woergaard 2001: Mentale rum og kohærens. In Hermes 26, 137-150. HHÅ, Århus.

Brünner, Gisela 1991: Redewiedergabe in Gesprächen. In Deutsche Sprache 19, 1-15. Erich Schmidt Verlag, Berlin.

Chisholm, Roderick M. 1946: The contrary-to-fact conditional. In Mind. A Quarterly Review of Psychology and Philosophy 55, 289-307. Kraus Reprint Limited, Nendeln.

Dijk, Teun A. van 1980: Macrostructures. An Interdisciplinary Study of Global Structures in Discourse, Interaction, and Cognition. Lawrence Erlbaum Associates Publishers, Hillsdale New Jersey.

Dijk, Teun A. van 1988: News as Discourse. Lawrence Erlbaum Associates, Hillsdale.

Dijk, Teun A. van \& Kintsch, Walter 1983: Strategies of Discourse Comprehension. Academic Press, New York, London.

Fauconnier, Gilles 1994: Mental Spaces. Aspects of Meaning Construction in natural language. Cambridge University Press, Cambridge (1985).

Fauconnier, Gilles 1999: Mappings in Thought and Language. Cambridge University Press, Cambridge (1997).

Fauconnier, Gilles \& Sweetser, Eve 1996: Cognitive Links and Domains: Basic Aspects of Mental Space Theory. In Fauconnier, Gilles \& Sweetser, Eve (ed.): Spaces, Worlds, and Grammar, 1-28. The University of Chicago Press, Chicago.

Grice, Paul 1975: Logic and Conversation. In Syntax and Semantics 3, 41-58. Harvard University Press, Cambridge.

Halliday, M.A.K. 1996: An Introduction to Functional Grammar. Arnold, London (1985).

Helbig, Gerhard \& Buscha, Joachim (2001): Deutsche Grammatik. Ein Handbuch für den Ausländerunterricht. Langenscheidt, Leipzig 1970. 


\section{8}

Jørgensen, Peter 1992: Tysk grammatik I-III. Gads Forlag, København (1973).

Klein, Wolfgang \& Stutterheim, Christiane von 1987: Quaestio und referentielle Bewegung in Erzählungen. In Linguistische Berichte 109, 163-183. Westdeutscher Verlag, Opladen Wiesbaden.

Klein, Wolfgang \& Stutterheim, Christiane von 1992: Textstruktur und referentielle Bewegung. In Zeitschrift für Literaturwissenschaft und Linguistik 22/1992 Heft 86: Textlinguistik, 67-92. Vandenhoeck \& Ruprecht, Göttingen.

Kutschera, Franz von 1974: Indicative Conditionals. In Schnelle, Helmut (ed.): Theoretical Linguistics bd. 1, 257-269. Walter de Gruyter, Berlin.

Lauridsen, Ole \& Poulsen, Sven-Olaf 1995: Tysk grammatik. Munksgaard, København.

Lewis, Charlton T. \& Short, Charles 1996: A Latin Dictionary. Oxford University Press, Oxford (1879)

Motsch, Wolfgang 1986: Anforderungen an eine handlungsorientierte Textanalyse. In Zeitschrift für Germanistik I, 86, 261-282. VEB Berlag Enzyklopädie Leipzig, Berlin.

Reichenbach, Hans 1947: Elements of Symbolic Logic. The Free Press, New York.

Sperber, Dan \& Wilson, Deirdre 1986: Relevance. Communication and Cognition. Basil Blackwell, Oxford.

Stutterheim, Christiane von \& Klein, Wolfgang 1989: Referential Movement in Descriptive and Narrative Discourse. In Dietrich, Rainer \& Grauman, Carl F. (udg.): Language Processing in Social Context, 39-76. North-Holland Linguistics Series 54. Elsevier Science Publishers B.V., Amsterdam.

Stutterheim, Christiane von 1997: Einige Prinzipien des Textaufbaus. Empirische Untersuchungen zur Produktion mündlicher Texte. Niemeyer Verlag, Tübingen.

Zifonun, Gisela \& Hoffmann, Ludger \& Strecker, Bruno 1997: Grammatik der deutschen Sprache I-III. Walter de Gruyter, Berlin. 